Пальчук П. М., к. ю. н., доч.

Київський національний торговельно-економічний університет,

м. Київ, Україна

GoogleScholarhttps://scholar.google.com.ua /citations?user=AEpnKNIAAAAJ\&hl=uk

\title{
ЗАПРОВАДЖЕНННЯ ЄВРОПЕЙСЬКИХ ВИМОГ ЩОДО МОБІЛЬНОСТІ ВИКЛАДАЧА В КОНТЕКСТІ РЕФОРМУВАННЯ ВИЩОЇ ОСВІТИ В УКРАЇНІ
}

У процесі реформування системи суспільних відносин в Україні змінюються підходи до розвитку системи вищої освіти. Фундаментальним чинником трансформації вищої освіти $\epsilon$ запровадження в освітній простір України механізмів та стандартів, закріплених Угодою про асоціацію між Свропейським Союзом та Україною [1]. Законодавство України, зокрема Закон України «Про вищу освіту» [2], визначає засади функціонування закладів вищої освіти, з урахуванням положень Угоди про асоціацію між Свропейським Союзом та Україною. Саме зазначені вище акти є законодавчої основою співпраці України та країн Свропейського Союзу та визначають напрями співпраці та подальшого розвитку.

При цьому визнаючи освіту як напрям пріоритетного розвитку Україна поступово запроваджує європейські стандарти в освітній процес, в тому числі декларується необхідність участі українських фахівців у науковій діяльності та освітній діяльності у Свропі та світі, запроваджуються механізми студентської і викладацької мобільності.

Але реалізація положень щодо мобільності викладача закладу вищої освіти передбачає формування дієвих правових, організаційних та фінансових механізмів, які забезпечуватимуть викладачу вищої школи можливість підвищувати свій професійний рівень у університетах країни світу, насамперед країн Європейського Союзу. При цьому не менш важливим є зворотній зв'язок, а саме створення умов для роботи викладачів вищої школи інших країн в Україні. 
Слід виходити з того, що академічна мобільність збільшує шанси особи на професійну самореалізацію, а також підвищує якість трудових ресурсів національної економіки. Вона стає відповіддю національних систем освіти на виклики глобального простору, жорстку конкуренцію на ринку освітніх послуг. Європейська комісія зазначає, що навчання за кордоном повинне стати стандартним елементом університетської освіти [3].

Таким чином, виходячи із необхідності реформувати національний освітній простір, як в цілому так і за окремими галузями знань, необхідно формувати як технічну (матеріальну) базу для розвитку закладів вищої освіти так i формувати відповідний кадровий потенціал. Але в більшості випадків викладачі українських закладів вищої освіти не забезпечені можливістю здійснювати свою професійну діяльність за стандартами країн Європейського Союзу. Зокрема це пов'язано із багатьма чинниками: організаційними, фінансовими.

Певним чинником, який ускладнює академічну мобільність викладачів $\epsilon$ різні вимоги щодо організації освітнього процесу у різних країнах. Зокрема це відноситься до організації освітнього процесу, вимог до викладача. Також при цьому необхідно враховувати особливості підготовки фахівців за різними спеціальностями. При цьому в сфері точних наук не може бути суттєвих розбіжностей у системі вищої освіти різних країн (фізика, сільське господарство, міжнародні економічні відносини тощо). Проте при підготовці фахівців, які можуть здійснювати свою професійну діяльність у сфері права або публічного управління кожна країни встановлює власні стандарти. Звичайно в частині формування теоретичних положень тієї або іншої науки існує єдність підходів, але це не дозволяє формувати ідентичні підходи до підготовки таких фахівців.

Проте в Україні необхідно продовжувати запровадження у сферу вищої освіти європейських стандартів щодо підготовки фахівців, які забезпечуватимуть належне функціонування вищої школи. При цьому не заперечується можливість встановлення спеціальних вимог щодо підготовки фахівців за окремими спеціальностями, проте має бути забезпечений єдиний методологічний підхід до підготовки фахівців, в тому числі працівників закладів вищої освіти. 


\section{Література}

1. Угода про асоціацію між Україною, 3 однієї сторони, та Європейським Союзом, Свропейським співтовариством з атомної енергії і їхніми державами-членами, з іншої сторони від 27 червня 2014 року. URL : https://zakon.rada.gov.ua/laws/show/984_011. (дата звернення 01 березня 2018).

2. Про вищу освіту : Закон України 1 липня 2014 року № 1556-VII. URL :https://zakon.rada.gov.ua/laws/show/1556-18. (дата звернення 01 березня 2018).

3. Академічна мобільність як фактор інтеграції України у світовий науково-освітній простір: Аналітична записка Національного інституту стратегічних досліджень URL : http://www.niss.gov.ua/ $\operatorname{articles} / 1421 /$ (дата звернення 01 березня 2018). 